DOI: $10.15290 /$ bsl.2017.11.08

\author{
Magdalena Roszczynialska \\ Wydział Filologiczny \\ Uniwersytet Pedagogiczny im. KEN w Krakowie \\ e-mail: m@roszczynialska.pl
}

\title{
Michała Cichego doświadczanie przestrzeni
}

Michał Cichy (ur. 1967) historyk, dziennikarz, członek kapituły Nagrody Literackiej Nike (1997-2002) „pprzeszedł na stronę literatury" ${ }^{1}$, wydając w 2014 roku tomik prozy Zawsze jest dzisiaj, a w 2017 swoistą jego kontynuację - Pozwól rzece płynaćć. Jak napisał w recenzji Tadeusz Sobolewski: „Obie jego książki są pochwałą uważności, która powstrzymuje bieg rzeczy"; nowatorstwo kontemplacyjnego spacerownika po Warszawie doceniono w 2015 roku Nagrodą Literacką Gdynia.

Przyszły prozaik studiował także historię sztuki, może więc zna esej Marii Gołaszewskiej z estetyki piękna natury, poświęcony chmurom³ ${ }^{3}$ których liczne opisy wplata w swoje prozy:

Chmury miały fakturę baraniego futra. Wyściełały całe niebo. Wszystkie odcienie szarości od srebra przez cynę do głębokiej ciemności kamienia litograficznego. Sfalowane, zmierzwione, pełne zagięć, przez które przeświecała biel.

1 T. Sobolewski, Michat Cichy, pustelnik z Ochoty, "Gazeta Wyborcza. Książki” 10.03.2017. Recenzje i omówienia twórczości Cichego zob. M. Zduniak-Wiktorowicz, Warszawski biotop, "Nowe Książki" 2014, nr 6, s. 34-35; J. Sobolewska, Bruki miasta, "Gazeta Wyborcza. Książki” 25.03.2014; A. Warnke, Michat Cichy, http://culture.pl/pl/tworca/michal-cichy (03.2017) [dostęp 01.10.2017]; rozmowa z autorem: Justyna Sobolewska, „Polityka” 11.03.2017 (materiał wideo: http://www.polityka.pl/tygodnikpolityka/kultura/1697386,1,kultura-na-weekend-rozmo wa-z-michalem-cichym-i-ksiazki-o-codziennosci.read) [dostęp 01.10.2017].

2 M. Cichy, Zawsze jest dzisiaj, Wołowiec 2014 (dalej jako Zjd); M. Cichy, Pozwól rzece płynać, Wołowiec 2017 (dalej jako Przp). Cytaty z obu książek podaję bezpośrednio w tekście, $\mathrm{w}$ nawiasie kwadratowym $\mathrm{z}$ numerem strony po przecinku.

3 M. Gołaszewska, Chmury. Esej z zakresu estetyki rzeczywistości, w: Poznanie i doznanie. Eseje z estetyki ekologii, red. M. Gołaszewska, Kraków 2000, s. 141-152. 
Niektóre z tych wzorów przypominały sęki albo izobary na mapie pogody [Zjd, s. 57].

Lub inny fragment:

[...] wróciły atlantyckie chmury. Pędziły stadami po niebie jak żywa wystawa holenderskiego malarstwa. Ciepły wiatr łopotał jak żagiel [Zjd, s. 63].

Lub:

O chmury, chmury, ulgo mego oka.

Tłuste jak bita śmietana wystrzeliwują $\mathrm{w}$ niebo, jak nieme wybuchy [...] [Przp, s. 91].

W przytoczonych deskrypcjach zwraca uwagę harmonijne połączenie zmysłowości z wyobraźnią znawcy sztuki, erudycja, a jednocześnie wrażliwość autora na zjawiska przyrody. Przywołuję esej z zakresu estetyki rzeczywistości po pierwsze dlatego, że w mojej opinii stanowi ona - po stronie receptywnej - analogię geopoetyki (tak, jak ta bada relację między przestrzenią a twórczymi praktykami kulturowymi, tak ona - relację rzeczywistości i doznającego podmiotu). Po drugie, ważniejsze, z tego powodu, że Gołaszewska upatruje w doznaniu chmur, stanowiącym „odrębny rodzaj przeżycia estetycznego", stymulator różnorakich: egzystencjalnych, intelektualnych, moralnych i w końcu też witalnych doświadczeń. Proza Michała Cichego stanowi zapis jego percepcyjnego nastawienia, otwartości na doznania inicjowane bodźcami napływającymi z przestrzeni codziennego życia.

Przestrzeń, jak rozumie ją fenomenologia, a za nią geografia humanistyczna, konstytuuje się w doświadczeniu życia ludzkiego ${ }^{4}$, innymi słowy doświadczanie przestrzeni to modus egzystencji. Zazwyczaj jest konceptualizowana jako miejsce, według uznanej definicji Yi-Fu Tuana będące "centrum znaczeń tworzonych dzięki doświadczeniu" ${ }^{5}$. Kłopot w tym, że doświadczenie jako "termin auratyczny" ${ }^{6}$ opalizuje wieloma sensami. Za Martinem Jayem wpisuję semantykę doświadczenia w podstawowe dychotomie: intencjonalności działania i gotowości poddania się ${ }^{7}$, prerefleksyjnego prze-

${ }^{4}$ H. Buczyńska-Garewicz, Miejsca, strony, okolice. Przyczynek do fenomenologii przestrzeni, Kraków 2006, s. 13; Maurice Merleau-Ponty pisze: „byt jest synonimem bycia usytuowanym” [M. Merleau-Ponty, Fenomenologia percepcji, przeł. M. Kowalska, J. Migasiński, Warszawa 2001, s. 275].

5 Cyt. za M. Lewicka, Psychologia miejsca, Warszawa 2012, s. 40.

6 M. Jay, Pieśni doświadczenia. Nowoczesne amerykańskie i europejskie wariacje na uniwersalny temat, przeł. A. Rejniak-Majewska, Kraków 2008, s. 15.

7 Tamże, s. 570. 
życia (Erlebnis) i znarratywizowanego doświadczenia (Erfahrung), holistycznego spełnienia (jak chciał John Dewey) i punktualnego doświadczenia granicznego (Roland Barthes).

Akcentując tytułową formułą trwanie, wskazuję, że najbardziej interesować mnie będzie jednak aspekt procesualny i receptywny doświadczenia, jest ono bowiem (według Tadeusza Buksińskiego) tym, co się przydarza8 ${ }^{8}$. Przestrzeń doświadczana jest $\mathrm{w}$ tym wypadku przestrzenią percepcyjną, wyznaczoną poczuciem własnego ciała oraz relacjami przestrzennymi pomiędzy ludźmi ${ }^{9}$, w zapisie literackim przyjmującą formę topografii afektywnej ${ }^{10}$.

Wybór deskrypcji jako podstawowej strategii podawczej umożliwia Cichemu maksymalną redukcję komponentów interpretacyjnych, pozostawiając miejsce dla wrażeń i emocji ${ }^{11}$. "Zmysły są jedną z dróg wyzwolenia się od napaści świadomości” - napisze [Przp, s. 8], ekran wyobrażeń i „wiedza nie może zasłaniać widzenia" [Przp, s. 21]. Zatem chodzi o to, by wyłączyć na ile to możliwe - kulturowe filtry percepcji, jak też, już na etapie postrzeżeń, starać się zatrzymać u progu obrazowania mentalnego.

Opis wobec narracji nie tylko pozostaje formą niedyskursywną, ale też analogonem miejsca jako pauzy w ruchu, zatrzymaniem opowiadania ${ }^{12}$. Pisarz objaśnia, że jego metoda twórcza polega na komponowaniu przestrzennym: swoje fragmentaryczne zapiski nakleja na kartony i układa na perskim dywanie, gdzie przyjmują kształt mozaiki ${ }^{13}$ (uwzględniając wybór do opisu głównie zjawisk atmosferycznych i kamiennych detali architektonicznych kalejdoskopu i lapidarium). Kompozycyjną regułą obu utworów jest fragmentaryczność, w planie wyrażania manifestowana jako parcjalność, a w planie treści ewokująca wspomnianą już semantykę niedyskursywności, niepochwytności poznawczej świata ${ }^{14}$, jego fenomenalności.

8 T. Buksiński, Przemiany doświadczenia, w: Doświadczenie, red. T. Buksiński, Poznań 2001, s. 7.

9 H. Libura, Percepcja przestrzeni miejskiej, Warszawa 1990, s. 59.

10 E. Konończuk, Psychogeograficzne poetyki miejskie, w: Nowe poetyki miejskie. Z problematyki urbanistycznej w literaturze XX i XXI wieku, red. M. Roszczynialska, K. Wądolny-Tatar, Kraków 2015, s. 24-25; E. Rybicka, Geopoetyka. Przestrzeń i miejsce we wspótczesnych teoriach i praktykach literackich, Kraków 2014, s. 269.

$11 \mathrm{O}$ antynomiach hermeneutyki miejsca i poetyki percepcyjnej por. E. Rybicka, Modernizowanie miasta. Zarys problematyki urbanistycznej w nowoczesnej literaturze polskiej, Kraków 2003, s. $104-106$.

12 P. Hamon, Czym jest opis?, przeł. A. Kuryś, K. Rytel, w: Narratologia, red. M. Głowiński, Gdańsk 2004, s. 234.

13 J. Sobolewska, rozmowa z Michałem Cichym, „Polityka” 11.03.2017.

14 Por. K. Bartoszyński, O fragmencie, w: tegoż, Powieść w świecie literackości. Szkice, Warszawa 1991, s. 141-164. 
Kierujący ruchem chmur i mas powietrza - wyzwalających postawę estetyczną pisarza - cyklon półkuli północnej ma tę, metaforyzującą rzeczywistość, cechę, że cyrkuluje "przeciwko obrotom wskazówek zegara" [Zjd, s. 67]. Doświadczanie przestrzeni wymaga czasu, utożsamić je można z jej uważną percepcją (uważnością). Tu idzie pisarz tropem znanym estetykom recepcji, np. spod znaku formalizmu: wydłużenie czasu ekspozycji na bodziec sprzyja estetyzacji perceptu.

Dylogia rządzi się zasadą retencji czasowej. Efekt ten uzyskano poprzez odwołanie się do cyklu przyrodniczego: astronomicznego i wegetacyjnego. Sekwencje otwierające i finalne wypełniają opisy iteracyjnych zjawisk przyrody: zachodu słońca, pierwszego śniegu, odwilży, rozkwitu malw, co ewokuje wrażenie trwania, mitycznego bezczasu (chwyt znany w twórczości Brunona Schulza, Piotra Szewca). Także bieg ludzkiego życia rytmizowany jest porządkiem czynności powtarzalnych, otwierania i zamykania drzwi, wyciskania soku z pomarańczy, wyprowadzania suki na spacery, bowiem, jak sądzi pisarz, "[m]achinalność jest zadomowieniem” [Zjd, s. 9] i to właśnie swojska rutyna objawia fenomen życia. Efekt odwlekania, spowolnienia czasu osiągnięto ponadto eksponując zjawisko niejednoczesności wrażenia i jego utrwalania, teraźniejszości doznania i zwłoki zapisywania. Techniką odraczania czasowego jest oczywiście opis, rozbudowana hypotypoza, np. "transmisja na żywo ze spadania liści” [Zjd, s. 60], dająca wrażenie wydłużenia odczuwanych interwałów czasowych.

Pisarz tematyzuje swoją preferencję do osiadłości i stabilizacji jako praktykowanie antropologii życia codziennego: „Sztuka siedzenia wymaga wyzbycia się iluzji, że życie jest gdzie indziej. [...] Rzeczywistość jest wszędzie" [Przp, s. 11]; największe doświadczenie można zdobyć „koło siebie”, nie $\mathrm{w}$ egzotycznych destynacjach podróżnych. Gest kondensacji skupiania, zatrzymania obecny jest w tytułach obu książek. Zawsze jest dzisiaj - przypominające Miłoszowy moment wieczny - łączy oksymoronicznie semantykę wieczności i teraźniejszości, trwania uobecniającego się w mijaniu i ulotności. W tytułowej formule Pozwól rzece płynać wybrzmiewa $\mathrm{z}$ kolei echo heraklitejskiej zgody na powszechną zmienność rzeczy, bycia jako stawania się, syntezy przeciwieństw. Liczne są sceny oglądania ruchu: chmur, słońca i księżyca, cienia, opadających lub rozwijających się liści, kroczenia pająka i trzmiela, lotu samolotów i ruchu pociągów, wprowadzającego narratora $\mathrm{w}$ bliski narkotycznemu trans, stan ekstatyczny.

W eseju programowym Antropologii codzienności Roch Sulima zauważył, że antropologowi tego nurtu przestrzeń jawi się jako niepoddana limitacjom, nie dzieli się na centrum i peryferie, gdyż codzienność jest tam, gdzie jestem ja ${ }^{15}$. Cichy wyznacza przestrzeń ruchem własnego ciała, li- 
nią widnokręgu oraz siecią sąsiedzkich relacji. Mieszka na warszawskiej Ochocie - skartowanie na mapę stolicy trasy jego spacerów unaocznia, że rzadko wykraczają poza jej terytorium i teren przyległej Woli. Należy zwrócić uwagę, że interesująca go przestrzeń znajduje się w fazie stawania, ma procesualny charakter, trwa w zmienności regresywnej i progresywnej, rozpadu i przebudowy, jest patchworkowa (często obrazowana figurą kontrastu).

Najciekawsze są "[m]iejsca na uboczu rzeczywistości” [Zjd, s. 48], ulice „bardzo boczne” (przykładowo: Zadumana, Armatnia), najczęściej gruntowe - choć metropolitalne, oraz "trzecioświatowe państwo kolejowe w wyrwie między Wolą a Ochotą" [Zjd, s. 42], jednak nie dlatego, że jako miejsca niczyje czy też figury detrakcji reprezentują różnicę kulturową, ale ponieważ są enklawami bujności. Pojawiają się określenia: gąszcz, dzikie działki, dżungla, czy - familektalne - „chęchy”. Trafnie zauważyła Małgorzata Zduniak-Wiktorowicz, że Cichy pisze o warszawskim biotopie, przestrzeni życia. Celebruje spotkania z kawkami, jerzykami, muchą, drobiazgowo opisuje agonię trzmiela, lot pawika, zmienność pór dnia i roku, wegetację roślin, których wiele zna "po imieniu” nazwy botanicznej. Zapisuje spostrzeżenie, że przyroda, jako bardziej trwała w czasie, ma przewagę nad środowiskiem antropogenicznym.

Kamień. Otoczak. Tylko że zrobiony z jasnoszarego marmuru. $\mathrm{W}$ jego formie znać było jeszcze ślady dawnej graniastości. [...] Kiedyś, kiedy stał się częścią stopnia czy parapetu, awansował z krainy natury do cywilizacji. Potem, pod koniec wojny [...] oddzielił się i wrócił we władanie przyrody, która obmywając go wodami i poddając sile tarcia, nadała mu prawie naturalną postać [Zjd, 40].

Przewodniczką po okolicy jest suka, Myszka, i to jej potrzeby stanowią praprzyczynę nie tyle wyboru, co raczej zgody ludzkiego podmiotu na kształt recypowanego wycinka przestrzeni; to suka, która „nie lubi głośnych ulic zawsze prosi żeby tamtędy [tj. uboczami - dop. M.R.] iść" [Zjd, s. 22]. Przyjęcie tej nieantropocentrycznej perspektywy powoduje, że mentalna mapa przestrzeni obejmuje miejsca atrakcyjne $\mathrm{z}$ psiego punktu widzenia. Ludzkie ich doświadczanie jest sekundarne, człowiek uczy się od zwierzęcia wyczulenia na, zazwyczaj pomijane, detale, swoistej uważności, prowadzącej do przestrzennych przewartościowań. Często bowiem okazuje się, że ta pozornie lichsza strona rzeczywistości kamufluje to, co ważne - jak np. niepozorna ulica Na Bateryjce, okazująca się faktyczną lokalizacją reduty Or-

15 R. Sulima, Antropologia codzienności, Kraków 2000, s. 9. 
dona ${ }^{16}$. Nie historia oficjalna interesuje jednak Cichego (pojawia się ona niejako przy okazji, na trasie spaceru z psem), prymat bierze codzienność. Zwykłe, wydawałoby się, ulice i domy Ochoty, nasycone są wartościami i znaczeniami wywiedzionymi z ludzkich oraz nie-ludzkich losów - jak zbieracza makulatury pana Jurka Damentki i psa Poldka, którego „przygarnął do swej bezdomności" [Przp, s. 40-41], co nadało lokalnej przestrzeni silną wartość emotywną ${ }^{17}$.

Rezygnacja z hierarchicznego ujęcia relacji człowiek-świat, a szerzej $\mathrm{z}$ dychotomii podmiot-przedmiot, czego sygnałem jest sensualizm (zmysły wszak przekraczają granicę skóry), zluzowanie kontroli ${ }^{18}$, w konsekwencji oznaczają także "[ż]ycie w zgodzie ze światem” [Przp, s. 42], pogodzenie z faktem, że "to, co się dzieje, zawsze ma powody się dziać" [jw.]; przy czym nie jest to ze strony pisarza gest eskapizmu, ale obowiązku rozumienia. Do postawy moralnego zobowiązania dochodzi się właśnie przez uprzednią rezygnację $\mathrm{z}$ antropocentryzmu. Można w tym miejscu przywołać słowa Ernsta Schumachera z książki Małe jest piękne (z 1973 r.): „Przywrócenie czułego stosunku do ziemi i zwierząt jest warunkiem odzyskania przez człowieka godności" ${ }^{19}$.

Współdzielenie animalnej (a konkretnie: psiej) perspektywy po części przestraja także zmysły, do preferowanej przez człowieka wizualności dołączając te bliskiego zasięgu, a samą percepcję wzrokową reorientując z makroperspektywy na skalę mikro. Amalgamacja mentalna polegałaby tu na tym, że Cichy chodzi co prawda z głową w chmurach, ale i z nosem przy ziemi,

16 Ujawniły ją badania archeologiczne dopiero w 2011 r. Rozsławiona wierszem jako symbol niezłomnego oporu reduta 54. materialnie nie istnieje, a forma jej upamiętnienia w rzeczywistej lokalizacji jest więcej niż skromna (fot. por. https://pl.wikipedia.org/wiki/Reduta_nr_54\#/ media/File:Reduta_Ordona_spontaniczny_pomnik.jpg) [dostęp 10.02.2018].

17 Trzeba zaznaczyć, że architektoniczna i urbanistyczna substancja miasta, szczególnie Warszawy, pobudza Cichego - zasadniczo redukującego ten komponent na rzecz prerefleksyjnego doświadczenia - do wpisywania weń także znaczeń symbolicznych i lektury w trybie alegorii. Np. losy budowniczych kamienicy przy Sękocińskiej 13 mogą stanowić figurę polskiego losu. Projektantami byli Jerzy Gelbard i Roman Sigalin - pierwszego zamęczyli Niemcy w Majdanku, drugiego, oficera polskiego, zabili Rosjanie w Charkowie, podobnie drugiego z braci Sigalinów. Trzeci z braci, Józef przeżył w Rosji i stał się później architektem socmodernistycznej Warszawy. Narzucającym się sygnałem warstwowości (więc potencjalnej figuralności) miasta są też materialne ślady, jak np. obecny wygląd budynku Banku Polskiego na rogu ulic Bielańskiej i Daniłowiczowskiej.

18 Por. fragment: „Architektów i urbanistów powinno się trzymać z daleka od miasta. Ci ludzie są niebezpieczni. Myślą o mieście jak o zadaniu inżynierskim, polegającym na cięciu i przestawianiu. Jak o czymś widzianym z perspektywy podniebnego boga, a nie z poziomu chodnika" [Przp, s. 102].

19 E.F. Schumacher, Małe jest piękne, przeł. E. Szymańska, J. Strzelecki, Warszawa 1981, s. 134. 
tj. uczy się rozpoznawać świat, jakim jawi się on psom, czy ogólniej zwierzętom. W skrajnym przypadku powie inkluzywnie: „kość była nasza” [Przp, s. 70], podsumowując rywalizację suki z kawką o resztki pożywienia. Zwrot ku afektywności przynosi - również umotywowane nieantropocentryczną pespektywą - uznanie emocji za kluczowe dla egzystencji tego, co żyje i umiera, co zanurzone jest w heraklitejską rzekę. I tu przewodnikami okazują się psy, Myszka i Boczuś:

Wielu z nas ma przy sobie najlepszych nauczycieli uczuć, jacy chodzą po ziemi. Codzienne ćwiczenia $\mathrm{z}$ tego, jak można się cieszyć na powrót bliskiego do domu. Zwyczajni profesorowie więzi. I mistrzowie odwiązania, bo ich czas trwa krócej niż nasz, i to oni szkolą nas z odchodzenia [Przp, s. 42] ${ }^{20}$.

Przestrzeń doświadczana jest w ruchu, konstytuowana ruchem „obrotów nieba" i własnego ciała, jest to przestrzeń doświadczenia kinestetycznego ${ }^{21}$. Forma tego ruchu to spacer, najczęściej w psim towarzystwie. Nie dziwi zatem, że ewokowane przez Cichego obszary stanowią przestrzenie tranzytu: torowiska, ulice, węzły komunikacyjne. Są one tranzytywne w dwojakim sensie, raz, że się przez nie przechodzi, dwa, że ich prymarną funkcją jest transfer. Ten paradygmat ustrukturuje również postrzeganie przestrzeni społecznej - wietnamski bar z ukraińską kelnerką, dom publiczny pod adresem Chłodna 39, ławka, na której umarł pijak - stanowią heterotopie. Pisarz przywołuje miejsca o zwiększonej gęstości ${ }^{22}$, jak narożnik (gdzie można się spotkać, minąć lub tylko pobyć), bramę sklepu, kiosk - nomen omen - „Ruchu” pani Janeczki i zakład fryzjerski Kaśki, lokalne centra wymiany informacji i serdeczności.

Przestrzeń, jaką wykreśla Cichy, jest koncentryczna - z ruchomym centrum ja: „Moja okolica, moje otoczenie, moja dziedzina, mój rewir, moje strony, mój obwód, moja wieś w mieście. [...] Moja wyspa w mieście. [...]. Okolica. Widnokrąg. Horyzont. Okręg. Cyrkuł" [Przp, s. 16-17]. Ponawiane w szeregu synonimicznym zaimki dzierżawcze nie akcentują wbrew pozorom posiadania, ale zrelatywizowanie przestrzeni do doświadczającego podmiotu. O doświadczeniu miejsca piszą fenomenologowie, że może mieć ono

\footnotetext{
${ }^{20}$ Może warto dodać, że nie chodzi wyłącznie o relację człowiek-inne zwierzę; w prozie Cichego liczne fragmenty dotyczą na równi emocji pomiędzy zwierzętami, np. psich przyjaźni.

21 M. Merleau-Ponty, Fenomenologia percepcji, s. 121-122.

22 R. Sulima, Antropologia codzienności, s. 103-104. Wagę tras, punktów, węzłów i krawędzi podkreśla antropolog za ustaleniami psychologii środowiskowej [A. Eliasz, Psychologia ekologiczna, Warszawa 1993].
} 
komponenty zależności, identyfikacji (tj. charakter poznawczy) oraz przywiązania $^{23}$. W przypadku pisarza do głosu dochodzi ten ostatni:

Opisuję Ochotę, bo ją kocham. Kocham Ochotę nie dlatego, że jest najpiękniejsza, tylko dlatego, że jest moja. Gdziekolwiek bym mieszkał, znalazłbym tam coś dla siebie [Przp, s. 18].

Ale także:

Patrzę na nie [kamienice] jak na coś w rodzaju własnych nieruchomości. [...] Użytek bez ciężaru posiadania [Przp, s. 14].

Michała Cichego doświadczanie przestrzeni można określić jako afekt miejsca, pisarz podkreśla zakorzenienie jako sposób własnej relacji z nim. Jeszcze jeden cytat:

ojczyzna bliższa, ważniejsza, rzeczywistsza, bo codziennie doświadczana. [...] raczej „większy dom” [niż „mała ojczyzna” - dop. M.R.]. Szczególny byt pomiędzy domem a ojczyzną, podwórko serca, umiejscowione uczucie przywiązania i przynależności łączące człowieka z czymś pomiędzy rodziną a narodem [Przp, s. 18].

Miernikiem zakorzenienia, jak zauważają psychologowie miejsca, są więzi społeczne ${ }^{24}$. Cichy jako dziennikarz ma predyspozycję do zadawania pytań otwartych, co jest znakomitym sposobem nawiązywania kontaktu, wywoływania opowieści bohaterów lokalnej codzienności: Ziutka, Krystiana, pana Henryka, pana Tadka, pani Ani, Janeczki, Kaśki, Rumcjasa i innych, a poprzez współuczestnictwo w rytuale rozmowy - zadzierzgania więzi ${ }^{25}$. Zalążkową formą narracji okazuje się nadanie imienia, uczłowieczenie nieznajomych sąsiadów: Nocnego Dziadzia, pana Scyzoryka, pana Skośnego, pana Stalina. Nie bez znaczenia wydaje się, że Cichy często nawiązuje relacje z bezdomnymi, kloszardami, złomiarzami, pijakami, trybem życia których jest zespołowość ${ }^{26}$. Pisarz jest świadom wagi sztuki rozmowy, dialogu - również tego toczonego z roślinami i zwierzętami, oraz pomiędzy nimi - dla ukonstytuowania się środowiskowej wspólnoty. Rozmowa, podobnie

\footnotetext{
23 M. Lewicka, Psychologia miejsca, s. 105.

24 Tamże, s. 232.

25 E.W. Rothenbuhler, Komunikacja rytualna. Od rozmowy codziennej do ceremonii medialnej, przeł.
} J. Barański, Kraków 2003, s. 55.

26 R. Sulima, Antropologia codzienności, s. 105. Ten nurt antropologii często sięga po zbliżony repertuar postaci, np. W.K. Pessel, Śmieciarze. Antyrecyklingowe studium z antropologii codzienności, Łomża 2008. 
jak zmysłowa percepcja, pozwala przekroczyć jednostkowość, rozszczelnić granicę podmiot-przedmiot (ja-świat). Albowiem:

Świat jest ciągły, w przestrzeni i w czasie. Podział tej ciągłości na przedmioty i zdarzenia pochodzi z naszego wnętrza, które nie zadowala się przeżywaniem przeżyć i puścić - ale dodatkowo chciałoby jeszcze zapamiętać, zmagazynować [Przp, s. 86].

Po drugie, samo doświadczanie jest relacją obustronną (w tym - doświadczanie miejsca), podczas którego, jak pisze Jay, „,coś musi zostać odmienione” 27.

Uwarunkowania procesu percepcji przestrzeni przez Cichego, np. spowolniony rytm poruszania się podczas spacerów, wymuszają określony sposób doświadczania, który sam pisarz nazywa skupioną uwagą stowarzyszoną z pozytywną emocją („,od dwóch kobiet brałem lekcje uwagi i przyjaźni na rogu swojej ulicy" [Przp, s. 12]). Skrupulatność w obserwacji i protokolarna dokładność opisu oraz swoiste połączenie „liryczności z trywialnością" 28 to cechy współdzielone $z$ innym warszawskim antropologiem codzienności, Mironem Białoszewskim, także czule zbierającym i przekazującym w nomenklaturze samego poety - „donosy rzeczywistości” oraz epifanie jej okruchów ${ }^{29}$.

Bycie-w-przestrzeni miasta pisarza nie polega na flanowaniu - które zakłada przecież spektakularyzację rzeczywistości i dystans do niej. Sytuacjonistyczny dryf $z$ kolei ukierunkowany jest niepraktycznie, to wędrowanie i gubienie się $\mathrm{w}$ oczekiwaniu na stany oderwania ${ }^{30}$. Tymczasem wędrówki pisarza uzasadnione są codzienną rutyną spacerów z psem, i - obok momentów ekstazy - wyostrzenie zmysłów mające miejsce w ich toku motywowane

\footnotetext{
27 M. Jay, Pieśni doświadczenia, s. 21.
}

28 R. Nycz, "Szare eminencje zachwytu". Miejsce epifanii w poetyce Mirona Białoszewskiego, w: tegoż, Literatura jako trop rzeczywistości, Kraków 2001, s. 231.

${ }^{29}$ O epifanijnej strategii Białoszewskiego por. R. Nycz, "Szare eminencje zachwytu”. Odmienną wykładnię strategii poety podaje Małgorzata Wichowska, łącząc epifanijność z afektywnością: „Te «epifanie» okruchów rzeczywistości, odsłaniające nieznane wymiary, błyski, szczeliny, opatrzone serdecznością, łagodnym humorem są w twórczości Białoszewskiego tym, co powoduje, że mimo różnych z nim «mijań», odnajdujemy tu bezcenne poczucie zakotwiczenia i wiarę w rzeczywistość jako coś nieprzypadkowego, trwałego" [M. Wichowska, Warszawa Białoszewska. (Te leżenia, latania i transe...), w: Tętno pod tynkiem. Warszawa Mirona Białoszezwskiego, red. A. Karpowicz, P. Kubkowski, W.K. Pessel, I. Piotrowski, Warszawa 2013, s. 303]. W moim przekonaniu nie tylko chodzi o podobieństwo wrażliwości i poetyk, ale i o aktualizację tradycji Cichemu zdarzają się świadome frazy „Białoszewskie”, np. „iście. Idzenie. Szłość” [Przp, s. 26]. Estetyka poety stała się przyczynkiem do projektu antropologicznego Sulimy, dla tych trzech autorów (Białoszewski - Sulima - Cichy) można wyznaczyć wspólną domenę: codzienność, z jej przemijalnością, kruchością.

30 E. Konończuk, Psychogeograficzne poetyki, s. 22. 
jest postawą uważności, a nie oderwania. Przypomina raczej procedury fenomenologicznej redukcji (epoché) i wglądu, od których różni się jednak celem, bowiem nie zmierza, jak one, do efektywnego uchwycenia istoty rzeczy (chyba, że za tę uznamy heraklitejską zmienność), lecz o jej aintelektualne doświadczanie ${ }^{31}$.

Wydłużenie czasu trwania zmysłowego odbioru świata zewnętrznego wynika tak z nieśpiesznego tempa poruszania się podmiotu, jak i z jakości samego percypowanego środowiska. „Ulice bardzo boczne”, przestrzeń patchworkowa, w której trwa „wiejska Warszawa” i rośnie infrastruktura nowoczesności, swoją różnorodnością (widoczną sedymentacją warstw historii ${ }^{32}$ ) stawiają opór doznaniu i poznaniu. Pełnią rolę podobną do chwytu udziwnienia w dziele sztuki, tj. zwiększają estetyczny potencjał codzienności, defamiliaryzując odbiór nie pozwalają na ronienie jej fenomenów ${ }^{33}$. Spowolnienie percepcji skutkuje zwiększeniem dokładności opisu doświadczanych bodźców, natomiast okazjonalne przyjmowanie zwierzęcej (psiej) pespektywy z nosem przy ziemi - powoduje, że pisarz zwraca uwagę na właśnie te przyziemne drobiny biotopu: szczeliny w chodnikowych płytach, bruk, kostkę Bauma, trylinkę. W efekcie otrzymujemy mikrologiczny opis rejestrowanej rzeczywistości.

Na wybór recypowanego wycinka przestrzeni zasadniczo mamy nikły wpływ - co prawda można odwrócić wzrok, jednak wrażenia audialne, olfaktoryczne, termoceptywne, kinestetyczne itp. są niezależne - niemniej istnieją pewne czynniki, kierunkujące uwagę na dany obiekt, czy też okoliczności sprzyjające doświadczaniu tego konkretnego fragmentu przestrzeni. Co ciekawe, w biografii Cichego stanowią one element losowy (doświadczenie jako zdarzenie) - mieszkańcem dzielnicy nie jest od urodzenia, bo już jako dorosły odziedziczył po ciotecznej babce Irce mieszkanie w przedwojennej kamienicy na Ochocie. O swojej dzielnicy powie: „Tu należę, chociaż nie tutaj się wychowałem" [Przp, s. 14]. Genetycznie stanowi więc ona, według typologii Małgorzaty Czermińskiej ${ }^{34}$, miejsce przesunięte, a faktycznie - obserwowane

31 Oba tryby relacji ze światem: i antropologiczną uważność, i doznania fenomenalne uważam za równorzędne (niezależnie od ich kolejności - lub wzajemnego warunkowania się w porządku doświadczenia) w postawie Cichego.

32 Jako historyk Cichy specjalizuje się w historii Zagłady, i z tego tytułu może być szczególnie wyczulony na wszelkie przejawy nieciągłości, uskoki, braki w substancji miasta i jego społeczności, czemu w obu pozycjach książkowych daje zresztą wyraz.

33 W. Szkłowski, Sztuka jako chwyt, przeł. R. Łużny, w: Teoria badań literackich za granica. Antologia, red. S. Skwarczyńska, Kraków 1986, t. 2, cz. 3, s. 10-28.

34 M. Czermińska, Miejsca autobiograficzne. Propozycja w ramach geopoetyki, „Teksty Drugie” 2011, nr 5, s. 183-199. 
(stałe), i ta dwoistość wspiera wspomniany już efekt multifokalizacji. Co ważniejsze jednak, rzecz w tym, że stałość miejsca nie jest dana (w odróżnieniu od niego samego nacechowanego już cudzą podmiotowością), ale osiągana w procesie doświadczeniowym.

Pisarz zadaje szereg pytań odnośnie przestrzeni swojego życia:

Skąd się bierze zadomowienie?

Jak zakorzenia się człowiek?

Jaką drogą otoczenie przechodzi do wnętrza?

W jaki sposób pobliże staje się miłością? [Przp, s. 13].

Interesuje mnie trzecie z nich, tyczące się problemów percepcji; otóż "otoczenie przechodzi do wnętrza" za pośrednictwem zmysłów. Cichy spaceruje okolicznymi ulicami ${ }^{35}$, których nawierzchnia jest patchworkiem asfaltu, kostki Bauma, trylinki i płyt chodnikowych, i ów codzienny widok, jak sądzę, daje kolejny impuls zainteresowaniu pisarza tymi drobnymi elementami architektury miasta. Nie bez znaczenia jest zapewne wrażliwość historyka, który w „zamordowanym mieście” ślady zburzonych obiektów kubaturowych odnajdzie w powierzchniach poziomych, w teksturze nawierzchni przechowującej zarys nieistniejącego już ukształtowania urbanistycznego (np. „Do okna [...] podchodzi wjazd ułożony z równiutkiej granitowej kostki. Kiedyś [...] musiała tam być brama kamienicy" [Zjd, s. 38]). Spotkanie z nimi nie oznacza jednak możliwości „rozmowy z kamieniem”, bowiem „kamienie nie są świadkami niczego. Nie widzą nas. Nie mają nawet oczu, które mogłyby zamknąć" [Przp, s. 54] - pisarz stara się powstrzymywać od hermeneutyki miejsca ${ }^{36}$, poprzestając na jego odczuwaniu.

35 Pisarz - być może mimowolnie, przywołując nader liczne szczegóły zamieszkiwanej przestrzeni - nieco myli tropy i nie tworzy odwzorowania przestrzeni urbanistycznej w skali 1:1. Konkretny adres jego zamieszkania można jednak odtworzyć z tekstów, mapując przywołane punkty odniesienia: landmarki, jak i zwykłe widoki. Skoro z okien mieszkania pisarz widzi kamienicę projektu Sigalinów z ołówkowymi wykuszami na fasadzie (a więc znajdującą się pod adresem Sękocińska 13), usytuowany ukośnie względem punktu obserwacji wieżowiec (być może na rogu Białobrzeskiej i Alej Jerozolimskich), leżącą w odległości około 200 m. linię kolejową oraz komin ciepłowni Wola i wieżę kościoła św. Wawrzyńca, można uznać, że zamieszkuje wysokie piętro kamienicy pod adresem Sękocińska 18. Spacer okolicznymi ulicami - szczególnie ul. Andrzejowską - potwierdza, że specyfiką ukształtowania lokalnej przestrzeni w jej najbardziej „przyziemnym” wymiarze nawierzchni jest istny melanż wszelkich rodzajów i kształtów materiałów budowlanych, reprezentujących przy tym rozmaite historyczne epoki i mody architektoniczne.

36 Można przyjąć, że Cichy chciał zaakcentować, iż w materialnej substancji miasta rozpoznaje nie tyle ślad utraconej bezpowrotnie przeszłości, ale przeciwnie, ma poczucie trwałej obecności w mieście, dzięki materialnym świadectwom ich pracy, jego byłych mieszkańców. 
Dzięki uruchomieniu całości sensorium stosunek Cichego do przestrzeni percypowanej można odbierać jako intymny, a jej regulatorem jest ciało doznające. Autor wybiera cielesne miary spacjalne, i kiedy czytamy o stopniach czy granitowych płytach o wymiarach określonych w stopach, to wiadomo, że nie chodzi (lub: nie tylko chodzi) o konwencjonalną jednostkę pomiarową, lecz o odniesienie do własnego ciała; pisarz rewindykuje $\mathrm{z}$ językowych automatyzmów leksykę metrologiczną: „I ja wedle siebie i swoich kroków mierzę co dzień moje sąsiedztwo, pobliże, mój codzienny obchód” [Przp, s. 18].

Jakości estetyczne przestrzeni ujawniające się $\mathrm{w}$ procesie poznawczym generują swoisty rezonans afektywny percepcji, odbrzmiewając $\mathrm{w}$ ciele podmiotu, np. brzydota boli [Zjd, s. 15]. Preferowaną przez estetykę środowiskową jakością jest umiarkowana różnorodnośćc ${ }^{37}$, zatem uniformizacja przestrzeni - podobnie jak brzydota - powoduje złe samopoczucie osoby jej doświadczającej. Szczególnie silne negatywne emocje, wyeksponowane nader ekspresywnym językiem, wzbudza u Cichego tzw. polbruk: „Kostka bauma, największy zwycięzca transformacji. Nie cierpię dziwki. Jest już właściwie wszędzie" [Zjd, s. 13]. Ten niweczący różnorodność, a zarazem środowisko przyrodnicze okolicy, materiał nawierzchniowy stał się także przedmiotem krytycznej uwagi innej „lokalnej” pisarki, Małgorzaty Baranowskiej ${ }^{38}$. Pomiędzy piszącymi o Ochocie - Cichym i Baranowską - występuje zresztą pewna zbieżność w postrzeganiu swojej dzielnicy, aczkolwiek zróżnicowane są tryby kontaktu z nią: w przypadku autorki Pamiętnika mistycznego jest to wspominanie, w przypadku Cichego - przeżywanie. Jednoczy ich pogląd o konstytutywnej dla tej części Warszawy obecności zwykłych ludzi (u pisarki: druciarzy, węglarzy, roznosicieli mleka), dospołecznych przestrzeni (np. pralni, lodziarni), przyrody („Za mojego dzieciństwa, z każdego punktu starej Ochoty, można było iść wśród rzeki zieleni" ${ }^{39}$ ) oraz o trwaniu jako prawidłowym sposobie zamieszkiwania (przeprowadziwszy się ponownie do dzielnicy

O „odmowie referencjalności, powierzchni znaczących, które nie prowadzą do znaczonych” pisała K. Szalewska w eseju Temporalna symbolika kamienia jako atrybutu melancholii miejskiej, w: Kamień w literaturze, języku i kulturze, t. 2, red. M. Roszczynialska, K. Wądolny-Tatar, Kraków 2013. Zagadnienia te oraz problematyka werbomotoryki i psychogeografii jako „retoryk bycia-w mieście" stały się m.in. przedmiotem zainteresowania autorki w książce Urbanalia miasto i jego teksty. Humanistyczne studia miejskie, Gdańsk 2017.

37 Tak m.in. uważa wyczulony na psychologiczne potrzeby mieszkańców architekt Ch. Alexander, por. tenże, Język wzorców, przeł. A. Kaczanowska, K. Maliszewska, M. Trzebiatowska, Gdańsk 2008 oraz M. Lewicka, Psychologia miejsca, s. 91.

38 M. Baranowska, Wracam na Ochotę, Warszawa 2011, s. 72-73. Informację o tym zbiorze felietonów zawdzięczam Małgorzacie Czermińskiej.

39 Tamże, s. 72. 
dzieciństwa Baranowska zapisuje „Dzisiaj nie zamierzam więcej wracać na Ochotę, ponieważ nie zamierzam się z niej za żadne skarby ruszyć. Mogę najwyżej opisywać trwanie tutaj" ${ }^{40}$ ). Zatem pozytywnie waloryzowana jest zażyłość z przestrzenią [Zjd, s. 16], zakorzenienie. W podawanym już cytacie przestrzeń określa się jako własną, tzn. bliskiego zasięgu. Bliskość ta ma dwa wymiary: fizyczny i emocjonalny. Wyznaczają one stosunek Cichego do przestrzeni, który, za psychologami miejsca ${ }^{41}$, można by nazwać wewnętrznością, odpowiednio: behawioralną i emocjonalną.

Ze względu na zmysłowe-bycie-w mieście poetyka doświadczenia przestrzennego pisarza ma formę somatopoetyki. Autor wykorzystuje rozmaite jej instrumenty: stosuje technikę fokalizacji zmysłowejej, nakłada kategorie cielesne na percepcję świata ${ }^{43}$, poprzez konfrontację z bytami nieantropocentrycznymi manifestuje ograniczenia własnej biologiczności, uwagę często kieruje ku temu, co abjektalne (np. resztki jedzenia, truchła zwierząt, złomiarze, nurki śmietnikowe i inni "nieczyści”), artykułuje - pytającą frazą sugestię o wzajemnej przenikliwości ciała i świata, niwelacji granic skóry. Najczęściej stosowanym przez niego chwytem somatopoetyki jest synestezja, czyli ten sposób przedstawienia, który łączy somatyczne z semantycznym (tytułem przykładu: „niebieskie szare chmury”, "głęboki jak buczenie fagotów kolor purpurowych jaworów", "ciemność - dotyk gęstniejącego chłodu", "zapach deszczu"), a w przypadku wrażeń słuchowych także onomatopeja („sypki szum coraz suchszych liści”).

Nastrojenie zmysłów dokonuje się ponadto w sytuacji ekstatycznego pobudzenia, w jaką Cichego wprowadza, znany już jako archaiczna technika ekstazy, ruch - bądź tylko jego obserwacja. Tego rodzaju stymulantami są chmury i pokrewne zjawiska atmosferyczne (wiatr, mgła) i astronomiczne (zmierzch, świt), trajektorie lotu samolotów, a główny psychoaktywator, łatwo dostępny, bo widziany z okna mieszkania, stanowi ruch pociągów: „powolny jednostajny ruch pociągów jest jak jazda kamery w kinie. Zawsze wprowadza mnie w łagodny trans" [Przp, s. 8]. Pisarz wyjaśnia, że film stanowi ukierunkowany i wzmocniony (w stosunku do rzeczywistości pozafilmowej) strumień bodźców, wskutek czego po wyjściu z kina „następuje błogosławiony kwadrans, kiedy dosłownie zamienia[m] się we wzrok

\footnotetext{
40 Tamże, s. 94.

41 M. Lewicka, Psychologia miejsca, s. 45; H. Libura, Percepcja przestrzeni miejskiej, s. 73.

42 A. Łebkowska, Somatopoetyka, w: Kulturowa teoria literatury, red. T. Walas, R. Nycz, Kraków 2012, s. 116-117. Przekonanie o udziale tej techniki w intersubiektywności podziela M. Rembowska-Płuciennik (por. tejże, Poetyka intersubiektywności, Toruń 2012).

43 A. Lebkowska, Somatopoetyka, s. 106.
} 
i słuch" [Zjd, s. 8], stan przypominający fenomenologiczny wgląd lub sytuację olśnienia (rytmizowanie i inspiracje fenomenologią także należą do repertuaru somatopoetyki). Zbliżone efekty uzyskiwane są w pajdialnej zabawie (paidea) - kompulsywne omijanie pęknięć chodnikowych płyt, zabawa „W karoserie” (czyli chłodzenie lub parzenie dłoni dotykaniem białej lub czarnej karoserii w gorący dzień), „w pajęczynki” (oszałamianie się spolaryzowanym drobinami deszczu lub mżawki światłem latarni) przynoszą Cichemu doświadczenie ilinktyczne, stanowiące, obok już omówionych, jedną $\mathrm{z}$ form doświadczania przez niego przestrzeni. Stymulanty paradoksalnie pełnią równocześnie funkcję trankwilizatorów, zachwyt nad fenomenem ruchu zatrzymuje ruch; pauza w ruchu jest przecież synonimem miejsca.

Iluminacje, olśnienia wzmagają procesy uwagi, ale przynoszą też wiedzę, na przykład taką, że warto zatrzymać się, zakorzenić. Tę mądrość czerpie pisarz ze świata przyrody, która znajduje się w nieustannym ruchu, a jednocześnie jej elementy mają swoje ustabilizowane miejsce $w$ biotopie, swoją ekologiczną niszę.

Drzewo nie cofa się ani o krok [...]. Pobieram od nich nauki.

Bycia na miejscu.

Ukorzenienia.

I odnowy przez całe życie [Przp, s. 85-86].

Pisząca o percepcji przestrzeni Elżbieta Szkurłat ${ }^{44}$, w doświadczeniu upatrując podstawowego pojęcia psychologii ekologicznej, geografii percepcji i geografii humanistycznej, wyróżnia jego cztery kręgi znaczeniowe: odbierane doznania, ich ślady w świadomości (np. reprezentacje poznawcze), skutki dla psychiki podmiotu (np. wykształcenie jakiejś postawy) oraz wiedzę praktyczną, tzw. "życiową mądrość". Zatem doświadczenie można rozpatrywać jako rodzaj aintelektualnego zasobu wiedzy i źródła sensu. I tak Michał Cichy „przechodzi" na stronę mądrości, jego proza nabiera charakteru mądrościowego, sentencjonalnego. Na zakończenie jedna z myśli pisarza (świadomego, głównie estetycznego, ryzyka uprawiania tego rodzaju refleksji), odnosząca się do jego receptywnej postawy otwartości:

Transcendencja to przekraczanie. Świadomość jest cieniutką warstwą [...]. Rządzi nami to, czego o sobie nie wiemy. Doświadczamy tego jako najwyższej siły, która nas przekracza. Ta moc w długiej perspektywie układa każdemu życie na podobieństwo tego, co jest jej głębokim ukrytym wzorem. Poddajemy się światu, poddając się sobie. Zgoda ze światem jest zgodą ze sobą [Przp, s. 61].

44 E. Szkurłat, Psychologiczne i kulturowe uwarunkowania percepcji środowiska, w: Percepcja wspótczesnej przestrzeni miejskiej, red. M. Madurowicz, Warszawa 2007. 


\section{Bibliografia}

Alexander Christopher, Język wzorców, przeł. A. Kaczanowska, K. Maliszewska, M. Trzebiatowska, Gdańsk: Gdańskie Wydawnictwo Pedagogiczne, 2008.

Baranowska Małgorzata, Wracam na Ochotę, Warszawa: Ośrodek Kultury Ochoty, 2011.

Bartoszyński Kazimierz, O fragmencie, w: tegoż, Powieść w świecie literackości. Szkice, Warszawa: IBL PAN, 1991, s. 141-164.

Buczyńska-Garewicz Hanna, Miejsca, strony, okolice. Przyczynek do fenomenologii przestrzeni, Kraków: Universitas, 2006.

Buksiński Tadeusz, Przemiany doświadczenia, w: Doświadczenie, red. T. Buksiński, Poznań: Wydawnictwo Naukowe UAM, 2001, s. 7-14.

Czermińska Małgorzata, Miejsca autobiograficzne. Propozycja w ramach geopoetyki, „Teksty Drugie" 2011, nr 5, s. 183-200.

Eliasz Andrzej, Psychologia ekologiczna, Warszawa: IP PAN, 1993.

Gołaszewska Maria, Chmury. Esej z zakresu estetyki rzeczywistości, w: Poznanie i doznanie. Eseje z estetyki ekologii, red. M. Gołaszewska, Kraków: Universitas, 2000, s. $141-152$.

Hamon Philippe, Czym jest opis?, przeł. A. Kuryś, K. Rytel, w: Narratologia, red. M. Głowiński, Gdańsk: Słowo/Obraz Terytoria 2004, s. 234-257.

Jay Martin, Pieśni doświadczenia. Nowoczesne amerykańskie i europejskie wariacje na uniwersalny temat, przeł. A. Rejniak-Majewska, Kraków: Universitas, 2008.

Konończuk Elżbieta, Psychogeograficzne poetyki miejskie, w: Nowe poetyki miejskie. Z problematyki urbanistycznej w literaturze XX i XXI wieku, red. M. Roszczynialska, K. Wądolny-Tatar, Kraków: Wydawnictwo Naukowe UP, 2015, s. 20-27.

Lewicka Maria, Psychologia miejsca, Warszawa: Wydawnictwo Naukowe Scholar, 2012. Libura Hanna, Percepcja przestrzeni miejskiej, Warszawa: Wydawnictwa UW, 1990.

Łebkowska Anna, Somatopoetyka, w: Kulturowa teoria literatury, red. T. Walas, R. Nycz, Kraków: Universitas, 2012, s. 101-136.

Merleau-Ponty Maurice, Fenomenologia percepcji, przeł. M. Kowalska, J. Migasiński, Warszawa: Fundacja Aletheia, 2001.

Nycz Ryszard, „Szare eminencje zachwytu”. Miejsce epifanii w poetyce Mirona Białoszewskiego, w: tegoż, Literatura jako trop rzeczywistości, Kraków: Universitas, 2001, s. 221-234.

Pessel Włodzimierz Karol, Śmieciarze. Antyrecyklingowe studium z antropologii codzienności, Łomża: Oficyna Wydawnicza Stopka, 2008.

Rembowska-Płuciennik Magdalena, Poetyka intersubiektywności, Toruń: Wydawnictwo Naukowe UMK, 2012.

Rothenbuhler Eric W., Komunikacja rytualna. Od rozmowy codziennej do ceremonii medialnej, przeł. J. Barański, Kraków: Wydawnictwo UJ, 2003.

Rybicka Elżbieta, Geopoetyka. Przestrzeń i miejsce we wspótczesnych teoriach i praktykach literackich, Kraków: Universitas, 2014.

Rybicka Elżbieta, Modernizowanie miasta. Zarys problematyki urbanistycznej w nowoczesnej literaturze polskiej, Kraków: Universitas, 2003. 
Schumacher E.F., Małe jest piękne, przeł. E. Szymańska, J. Strzelecki, Warszawa: PIW, 1981.

Sobolewska Justyna, „Polityka” 11.03.2017 [materiał wideo: http://www.polityka.pl/ tygodnikpolityka/kultura/1697386,1,kultura-na-weekend-rozmowa-z-michalem -cichym-i-ksiazki-o-codziennosci.read].

Sobolewska Justyna, Bruki miasta, „Gazeta Wyborcza. Książki”, 25.03.2014.

Sobolewski Tadeusz, Michat Cichy, pustelnik z Ochoty, "Gazeta Wyborcza. Książki”, 10.03.2017.

Sulima Roch, Antropologia codzienności, Kraków: Wydawnictwo UJ, 2000.

Szalewska Katarzyna, Temporalna symbolika kamienia jako atrybutu melancholii miejskiej, w: Kamień w literaturze, języku i kulturze, t. 2, red. M. Roszczynialska, K. Wądolny-Tatar, Wydawnictwo Naukowe UP, Kraków 2013, s. 355-368

Szalewska Katarzyna, Urbanalia - miasto i jego teksty. Humanistyczne studia miejskie, Gdańsk: Słowo/Obraz Terytoria, 2017.

Szkłowski Wiktor, Sztuka jako chwyt, przeł. R. Łużny, w: Teoria badań literackich za granica. Antologia, t. 2, cz. 3, red. S. Skwarczyńska, Kraków: Wydawnictwo Literackie, 1986.

Szkurłat Elżbieta, Psychologiczne i kulturowe uwarunkowania percepcji środowiska, w: Percepcja współczesnej przestrzeni miejskiej, red. M. Madurowicz, WUW, Warszawa 2007, s. 63-72.

Warnke Agnieszka, http://culture.pl/pl/tworca/michal-cichy [dostęp 01.03.2017].

Wichowska Małgorzata, Warszawa Białoszewska. (Te leżenia, latania i transe...), w: Tętno pod tynkiem. Warszawa Mirona Białoszewskiego, red. A. Karpowicz, P. Kubkowski, W.K. Pessel, I. Piotrowski, Warszawa: Lampa i Iskra Boża, 2013, s. 290-308.

Zduniak-Wiktorowicz Małgorzata, Warszawski biotop, „Nowe Książki” 2014, nr 6, s. 34-35.

https://pl.wikipedia.org/wiki/Reduta_nr_54\#/media/File:Reduta_Ordona_spontani czny_pomnik.jpg).

\section{Experience of Space in Michał Cichy's Writings}

\section{Summary}

The author analyzes the poetics of affective topography in the works by Michał Cichy. Her close reading of the texts demonstrates that the interpretative parts gradually give way to the record of the bodily and sensual. Cichy's emotive descriptions of his Warsaw neighbourhood, Ochota provide insight into the life of the place and its inhabitants. His poetics frequently reveals such features as micrological descriptions and the use of animal (canine) perspective in experiencing place. This last tenet places Cichy's works within the framework of (non-anthropocentric) phenomenology of perception and anthropology of everyday life.

Keywords: somatopoetics, animal studies, perception, phenomenology, anthropology of everyday life 